\title{
P02.30. Assessment of hypnotizability in clincal research: development, reliability, and validation of the Elkins Hynotizability Scale
}

\author{
G Elkins, W Fisher, A Johnson \\ From International Research Congress on Integrative Medicine and Health 2012 \\ Portland, Oregon, USA. 15-18 May 2012
}

\section{Purpose}

Hypnotherapy has been shown to be an effective treatment for some conditions such as pain, anxiety, chemotherapy side effects, and hot flashes. Measurement of hypnotizability is essential for research. There are a number of scales that have been developed to measure hypnotizbility in clincal research. However, the currently available scales suffer from a number of important shortcomings such as time for administration, validity concerns, and item difficulty. As a result, hypnotizability is rarely measured in clinical work and research has been limited. The purpose of this study was to develop a new scale to measure hypnotizability that met the following criteria: (1) administration in 30 minutes or less; (2) correlation of 80 or better with the Stanford Hypnotic Susceptibility Scale; and (3) improved item selection.

\section{Methods}

A 12 item hypnotizability scale (Elkins Hypnotizability Scale; EHS) was developed with the wording for each item based upon the clinical experience of the Principal Investigator from administration of the EHS in clinical work and receiving feedback from patients and expert reviewers.

\section{Results}

The average time for administration was 27 minutes. Test-retest reliability was $\mathrm{r}=.93$. The correlation between the EHS and the Stanford Hypnotic Susceptibility Scale-Form C was $\mathrm{r}=.91$.

Baylor University, Waco, USA

(c) 2012 Elkins et al; licensee BioMed Central Ltd. This is an Open Access article distributed under the terms of the Creative Commons Attribution License (http://creativecommons.org/licenses/by/2.0), which permits unrestricted use, distribution, and reproduction in any medium, provided the original work is properly cited.

\section{Conclusion}

Results support the development of an improved scale to measure hypnotizability. The results demonstrated that the scale can be administered within 30 minutes (as compared to 75 minutes for the Stanford Hypnotic Susceptibility Scale-Form C). In addition, the scale demonstrated strong reliability. The correlation between the EHS and Stanford Hypnotic Susceptibility Scale-Form C was also strong and significant, suggesting that the EHS measures the same domain of hypnotic responding and is therefore likely to be a valid measure. The present study reports on initial scale development, and the utility of the EHS in clinical research is presently being determined.

Published: 12 June 2012

doi:10.1186/1472-6882-12-S1-P86

Cite this article as: Elkins et al:: P02.30. Assessment of hypnotizability in clincal research: development, reliability, and validation of the Elkins Hynotizability Scale. BMC Complementary and Alternative Medicine 201212 (Suppl 1):P86.

Submit your next manuscript to BioMed Central and take full advantage of:

- Convenient online submission

- Thorough peer review

- No space constraints or color figure charges

- Immediate publication on acceptance

- Inclusion in PubMed, CAS, Scopus and Google Scholar

- Research which is freely available for redistribution

Submit your manuscript at \\ (Ciomed Central}

